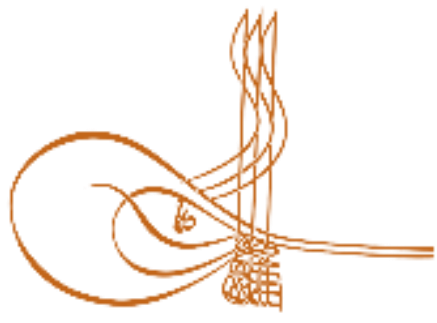

www.turkishstudies.net/social
Turkish Studies - Social Sciences

eISSN: $2667-5617$

Research Article / Araștırma Makalesi

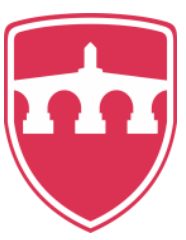

INTERNATIONAL

BALKAN

UNIVERSITY

Sponsored by IBU

\title{
Kemalizmi Teorileștirme Sürecinde Kadro Dergisi’nin Rolü
}

Kadro Journal's Role in During the Theorisation of Kemalism

\author{
İhsan Ömer Atagenç*
}

\begin{abstract}
Kadro Jorunal is one of the main journals in Atatürk period guiding the Turkish thought life. Prominent intellectuals of this period creating the founder staff of this journal. In the 1930s, the Kadro Magazine played a critical role in the transformation of Kemalism from practice to theory. During the Interwar Period, The Journal sought ways for Kemalism to become an independent and unique theory in economy and social policies, especially in foreign policy. This process led the magazine towards a search for independence from Western states representing capitalism and the USSR representing socialism. The new orientation, which was described as the "Third Way" in the 1930s and sought to be a solution to the urgent needs of the period, enabled Kemalism to settle into a model of "statist", "authoritarian" but facing socialism in the economy in the 1930s. The statist and authoritarian aspect of these principles, which the Kadro put forward under the shadow of the power of the period, ensured that Kemalism was similar to the fascism that was rising in continental Europe in the relevant period. In response to the statist direction in the political direction of the magazine, the Kadro that reflects the spirit of the 1930s and proposes a veiled socialist economy, will become the side of the struggle between Celal Bayar and Ismet Inönü in power and will be defeated in Atatürk's short-term preferences. The closure of the magazine by Atatürk himself has been interpreted as a difference of opinion between the magazine and Atatürk. This study aims to discuss whether the relations between Atatürk and the Kadro are in line with the general comments made in light of the current findings.
\end{abstract}

Structured Abstract: The question of whether Kemalism is an "ideology" is often discussed in the literature. The debate on the subject is generally between Kemalism having a holistic ideology and having no ideological qualities. As an alternative to both views, this work will attempt to define the limits of Kemalism's ideological qualities. In other words, it will try to provide an alternative interpretation to the wholesale approaches to whether Kemalism is an ideology or not. It will be seen that a quest was made in the 1930s for the ideological nature of Kemalism to become more evident. One of the most concrete examples of this quest is the Kadro Magazine, which was founded by intellectuals with close views on power in the 1930s. The Kadro Magazine environment is a publishing environment that seeks ways for Kemalism to become an independent and unique ideology. The state's ability to conduct an independent policy in foreign policy has also required the

* ID

Dr. Öğr. Üyesi, Kırklareli Üniversitesi, İ.İ.B.F., Uluslararası İlişkiler Bölümü

Asst. Prof. Dr. Kirklareli University, F.E.A.S., Department of International Relations

ORCID: https://orcid.org/0000-0002-8853-4749

atagencomer@yahoo.com

Cite as/ Atıf: Atagenç, İ.Ö. (2020). Kemalizmi teorileştirme sürecinde kadro dergisi'nin rolü, Turkish Studies - Social, 15(1), 83-99. https://dx.doi.org/10.29228/TurkishStudies.40062

Received/Geliş: 08 December/Aralık 2019

Accepted/Kabul: 25 February/Şubat 2020

Checked by plagiarism software

Copyright $(\subset$ INTAC LTD, Turkey 
establishment of a unique model in the internal political regime. In this context, Kemalism, under the leadership of the Kadro, tried to be built as an alternative path independent of capitalism and socialism. The Kadro's alternative discourse, on the other hand, is built mainly on economic foundations. The priority given by countries to develop their economies in the interwar period, as well as the shake-up caused by the World Economic Crisis of 1929, led to the development of Turkey's priorities on economic issues. On the one hand, the economic crisis, on the other hand, the fact that the world is moving towards the brink of a new war has given rise to a "development" - oriented debate in Turkey. This new period, called "statism" in economics, can be described as the sum of short-term practical solutions in terms of solving the problems experienced in the 1930s, rather than a long-term project. While the implementation of the principle of statism took place at the government level under the partnership of Atatürk and the then Economy Minister Bayar, a new journal initiative led by intellectuals close to power emerged in order to gain an ideological character for Turkey's new practices. Organized under the name of "Kadro", it sought to give an ideological quality to a state that came to the fore with new intellectual environmental practices. Both the new needs of the state and the fact that the team forming the Kadro had a political background close to socialism ensured that the economy was the main agenda when building Kemalism. The staff, who connected the existence of an independent and strong Republic of Turkey to an independent and strong economy, tried to implement an idea that resembled the Soviet economic model in many ways, envisioned a planned and centralized development model. The similarity of the statism practice of the 1930s with the New Economic Policy (NEP), which was implemented in the USSR during Lenin's reign, further cemented cadre's power. The Kadro magazine's search for an alternative in the political field is based on the ability to build a model unique to Turkey as a result of a national liberation struggle with a tendency towards socialism. The evaluation of the Lenin-influenced theory of imperialism in the central-periphery countries dilemma led to the emergence of a new approach to socialism. The Kadro's idea of socialism, which is not based on "class conflict", envisages the establishment of a classless society through the National War of independence. The new idea that the Kadro is trying to build on the harmony of classes instead of class conflict has been equivalent to the idea of a corporatist society in continental Europe that has resulted in fascism and Nazism, and evaluations have been made that the Kadro's idea is a kind of fascism. When it is thought that fascism appeared in continental Europe as a response to the imperialist intervention of the West, it will be encountered by the fact that the Kadro took into account the emergence of the reaction against imperialism, not by praising fascism in his various writings. The establishment of the Kadro by the directives of Atatürk demanded that the publication policy of the magazine be in harmony with the practices of the power as much as possible. However, in the new era when Celal Bayar was economy minister, the cadre circle was distant with İşbank group, which was called "aferists" and was close to Bayar. In the new economic model, the Kadro did not consider it appropriate for İşbank's environment, which the state considered to be exploiting its resources, and therefore Bayar, to take part in the statehood policies. This new process, which emerged in the 1930s, would result in a number of conflicts within power as well. The first case of the intra-power struggle began with Atatürk bringing Celal Bayar to the Ministry of economy and the removal of Prime Minister Ismet Inönü from a priority issue of the state. The tension that started will become more tense in the process and the process will turn towards a competition within the power. Atatürk's obligatory confidence in Bayar in order to solve the current problems in a short time has taken Inönü out of this equation and Inönü has started to share his views on statehood and criticism of the current administration with the public through the Kadro pages. Inönü's use of the Kadro as an opposition tool has enabled the Kadro to be placed on the target board in the process. The work initiated by the Kadro environment will not last much longer in an inpower competition and the process of theorizing Kemalism will be suspended for a long time. This study analyses the contents and limits of the Kadro's contribution to Kemalism as an ideological character and in this context seeks answers to the question of whether Kemalism is an ideology. In addition, this study will critically analyze some of the general comments in the literature about the staff. Because although the debate about the political orientation of the Kadro magazine is quite evident, the closure of the Kadro and its relations with Atatürk are still open to discussion. For this reason, an analysis of the relations between the statism model of the 1930s and the Kadro's view of statism has been made and it will be debated whether the process of Kadri's closure was due to an ideological difference or because it had become a side of an internal conflict.

Keywords: Turkish political life, Kemalism, Kadro Journal, Third Way

Öz: Kadro Dergisi, Atatürk döneminde Türk düşünce hayatına yön veren dergilerden bir tanesidir. Dönemin önde gelen entelekütelleri bu derginin kurucu kadrosunu oluşturmaktadır. 1930'lu yıllarda Kemalizmin 
pratikten teoriye doğru dönüştürülmesi sürecinde Kadro Dergisi'nin kritik bir rolü bulunmaktadır. İki dünya savaşı arası süreçte dergi, Kemalizmin başta dış politika olmak üzere ekonomi ve toplumsal politikalarda bağımsız ve özgün bir teori olabilmesinin yollarını aramıştır. Bu süreç dergiyi, kapitalizmi temsil eden Batılı devletler ve sosyalizmi temsil eden SSCB'den bağımsız bir arayışa doğru sürüklemiştir. 1930'lu yıllarda "Üçüncü Yol" olarak tarif edilen ve dönemin acil ihtiyaçlarına çözüm olmaya çalışan yeni yönelim Kemalizmin 1930'lu y1llarda “devletçi”, "otoriter” ancak ekonomide yüzü sosyalizme dönük bir modelin içine yerleşmesini sağlamıştır. Kadro'nun dönemin iktidarının gölgesi altında ortaya koyduğu bu ilkelerin devletçi ve otoriter yönü Kemalizmin ilgili dönemde Kıta Avrupası'nda yükselen faşizmle benzerlik kurulmasını sağlamıştır. Derginin politik yönelimdeki devletçi yöne karşıllık olarak ekonomide 1930'lu yılların ruhunu yansıtan ve üstü örtülü bir sosyalist ekonomi öneren Kadro, iktidar içinde Celal Bayar ile İsmet İnönü arasında yaşanan mücadelenin tarafi haline gelecek ve Atatürk'ün kısa vadeli tercihlerinde mağlup olacaktır. Kadro'nun bizzat Atatürk tarafından kapatılması dergi ile Atatürk arasındaki görüş farklılığı olarak yorumlanmıştır. Bu çalışma Atatürk ile Kadro arasındaki ilişkilerin yapılan genel yorumlara uygun olup olmadığını mevcut bulgular ışığında tartışmaya açmayı amaçlamaktadır.

Anahtar Kelimeler: Türk Siyasal Hayatı, Kemalizm, Kadro Dergisi, Üçüncü Yol

\section{Giriş}

Kemalizmin bir "ideoloji” olup olmadığına dair tartışmalar halen devam etmektedir. Bu tartışmaların halen devam etmesinin en önemli nedenlerinden bir tanesi Kemalizmin kurucu iktidarının hem içindeki hem de eylemindeki dönüşümlerdir. Tüm bu farklılıklara rağmen Türkiye Cumhuriyeti'nin kuruluş süreci yalnızca bir devletin inşası değil aynı zamanda yeni bir ideolojinin de kuruluş sürecini ifade etmektedir. Literatürde kimi zaman Kemalizmin evrensel pek çok ideoloji ile kurduğu bağlar veya 1920'li ve 1930'lu yıllardaki uygulamaları üzerinden çeşitli kavramlar ile tanımlanmaya çalışılmışır. Ancak bu tanımlama çabalarının hiçbiri Kemalizmin tam olarak ne olduğunu anlamaya yeterli değildir. Zira Kemalizmin "idealleri” ile Türkiye'nin o dönemdeki "gerçekleri" arasında tam bir irtibat bulunup bulunmadığı henüz cevaplanmış bir soru değildir. Atatürk'ün hayatta olduğu dönemden itibaren çok çeşitli Kemalizm yorumlarının ortaya çıktığı görülmektedir. Yorum farklılıkları Atatürk'ün ölümünden sonra -pek çoğu da iktidarının meşruiyetini sağlayabilmek için- tırmanarak devam etmiştir. Bu dönem ile ilgili yapılabilecek tek sağlıklı değerlendirme kurucu iktidarın öncü olduğu bir ideolojinin hayata geçirilmesidir. Kemalist iktidar bu dönemde kendi ideolojisini ortaya çıkarabilmek için önemli bir çaba sarfedecektir. 1930'lu yıllar itibariyle Kemalizmin ideoloji arayışının en somut örneği "Kadro Dergisi” etrafında ortaya çıkan, iktidar desteğini arkasına almış olmasına rağmen çok uzun ömürlü olmayan bir aydın hareketidir. Kadro Dergisi, Kemalizme ideolojik bir altyapı oluşturma noktasında oldukça önemli bir boşluğu dolduracak, Cumhuriyetin geleceğine nasıl yön verilmesine gerektiğine dair oldukça önemli ipuçları verecektir.

$\mathrm{Bu}$ çalışma tarihsel olarak Kemalizmin kuruluş süreci ile sınırlıdır. Bir başka ifadeyle 19231938 yıllarını kapsayan ve Atatürk'ün liderlik dönemindeki arayışlar üzerinden bir değerlendirme yapılacaktır. Atatürk döneminin merkeze alınmasının sebebi, Atatürk'ün son döneminde başlayan ve ölümünden sonraki döneme yansıyan iktidar çatışmasının Kemalizmin gelişimindeki olumsuz roldür. Zira 1938 sonrası süreçte çeşitli biçimlerde ortaya çıkan "Atatürk" imajları arasındaki farklılık bir düşünsel tartışmadan ziyade bir iktidar mücadelesinin ve bir meşruiyet mücadelesinin doğal bir sonucu olarak Türk siyasal hayatını etkilemiştir. Bu bağlamda Atatürk dönemi ile sonraki dönemler arasında herhangi bir "ardıllık-öncüllük" tartışmasına girmeden yalnızca Atatürk dönemi merkeze alınarak bir değerlendirme yapılacaktır.

\section{Kemalizmin "İdeoloji”" Olma Sorunsalı}

Kemalizmin kuruluş sürecine denk gelen Millî Mücadele döneminden itibaren başta Atatürk olmak üzere devletin karar alıcıları herhangi bir ideoloji ile doğrudan temas etmekten kaçınmışlardır. Kurulacak yeni ülkenin herhangi bir "-izm” temeline inşa edilmesi çok ciddi başka problemleri de 
beraberinde getirecektir. $\mathrm{Bu}$ problemlerden en önemlisi mevcut ideolojilerden birisinin tercih edilmesinin aynı zamanda de facto devletin uluslararası alanda bir tercih yapma ihtimalini de ortaya çıkaracaktır. Bu konunun literatürde yeteri kadar ciddiye alınmadığ 1 görülmektedir. Bu konuya geçmeden önce Kemalizmin evrensel ideolojiler ile arasındaki ilişkinin sınırlarına değinmek gerekmektedir. Burada ise ideoloji kavramından kastedilen husus Kemalizmin Marksizm, liberalizm vb. ideolojiler gibi temel metinlere ve kaynaklara sahip, düşüncenin önceden yarattığı etkiye bağl1 olarak toplumsal devrimlerin gerçekleşmesini sağlayan, teori öncelikli veya teori ile pratiği aynı potada eriten, determinist ve toplumsal yapının işleyişine dair öncül öngörüye sahip bir ideoloji olmamasıdır. Kemalizm, Milli Mücadele sürecinin ortaya çıkardığı eylemin düşünsel bir anlam kazanma çabasına verilen addır (Kışlal1, 2000: 143). Kemalizmin elbette evrensel ideolojiler ve gelişmeler ile yakından bir irtibatı bulunmaktadır. II. Selim döneminde yoğun bir biçimde başlayan "Batılılaşma" sürecinin bir sonucu olarak Osmanlı Devleti'nin son dönem aydınlarından Cumhuriyetin kuruluş sürecindeki aydınlara kadar Batı düşüncesi ile kurulan ilişki Türkiye Cumhuriyeti'nin kurucu ideolojisinin de bu çerçevede ortaya çıkmasını sağlamıştır. Ancak her ne kadar Kemalizm evrensel ideolojiler ile yakın bir temasta bulunsa da kendisini doğrudan belirli ideolojilerin ardılı olarak görme eğiliminden mümkün olduğu kadar uzakta kalmıştır (Mardin, 2013: 181).

Bu durumu ortaya çıkaran sebeplerden biri kurucu iktidarın aydınlarının dünya görüşleri arasındaki farklılıklardır. İttihat ve Terakki döneminin yükselişinden itibaren ortaya çıkan bu farklılıklar Cumhuriyet dönemine de sirayet etmiştir. Kemalizmin önemli tarihsel ve düşünsel referanslarından olan İttihat ve Terakki'nin kuruluş sürecinde de benzer farklılıklara temas etmek mümkündür. Örgütün iki ana kanadından bir tarafın lideri Ahmet Rıza iken diğer tarafın lideri Prens Sabahattin'dir (Zürcher, 2014: 137). Örgütün düşünsel olarak iki ana kanada bölünmesinde milliyetçilik, otoriterlik, merkeziyetçilik kavramlarının oldukça önemli bir rolü bulunmaktadır. İttihat ve Terakki'ye önderlik edecek olan Ahmet Riza kadrosunun milliyetçi, otoriter ve merkeziyetçi niteliği partinin iktidar döneminde de etkili olacaktır. Hatta bu etki Milli Mücadele dönemi ile birlikte Kemalizmin kuruluş sürecinde de kendisini gösterecektir. Ahmet Rıza'nın burada birey olarak bir kuramcıdan çok bir örgütçü olarak görülmesi gerekmektedir. Zira Ahmet Rıza'nın buradaki rolü bir ideolojik liderlik değil, ikiye bölünen örgütün bir kanadının yönetimsel olarak sembol ismi haline gelmesidir. Bu kanat, İttihat ve Terakki'nin iktidar döneminin ardından Türkçülük akımının başat temsilcisi haline gelecektir (Sönmez, 2012: 101-102).

Kemalizmin oluşum sürecinde "milliyetçilik", "merkeziyetçilik" ve "otoriterlik" kavramlarının başat özellikler olduğunu söylemek mümkündür (Köker, 2002: 111). Bu bağlamda da Avrupa'da I. Dünya Savaşı öncesinde ortaya çıkan uluslaşma sürecinin, kendine yeterli ve içine kapalı bir ekonomi sürecinin, emperyalist tehdit altındaki devletlerin sınırlarını koruma çabasının önemli bir rolü bulunmaktadır. Kemalizmin düşünsel olarak tarif edilirken "Türk milliyetçiliği" kavramının ilk akla gelen niteliklerden biri olması tesadüf değildir. İmparatorluklardan ulus-devletler çağına geçiş sürecinde Osmanlı Devleti'nin ülkesel ve ekonomik güvenliğinin sağlanması için gerek siyasal, gerek kültürel gerekse ekonomi alanında ulusal eksende politikaların tercih edildiği görülmektedir. Aynı durum Milli Mücadele döneminde de devam edecektir. İttihat ve Terakki iktidarından Kemalizme bir süreklilik olarak tanımlanabilecek bu durum 1920'li yıllardan itibaren daha somut bir biçimde karşımıza çıkacaktır (Kışlalı, 2000: 146).

Osmanlı Devleti'nin son döneminden Cumhuriyetin kuruluşuna kadar olan süreçte ülkedeki aydınların düşünsel üretimlerindeki hareketlilik genel itibariyle savaş ortamındaki krizlere çare bulabilmek amacını taşımaktadır. Başka bir ifadeyle dönemin düşünsel gelişimi mevcut durumdan kurtuluşa çare aramak ile sınırlı kalmıştır. Mevcut krizlerin aşılmasının ardından ortaya çıkacak bir "normalleşme" sürecinde ülkenin geleceğinin hangi ilkeler üzerine inşa edileceği ya da inşa edilmesi gerektiğine dair fikirler yeteri kadar gelişim gösterememiştir. Kriz döneminde zenginleşen düşünsel ortam Osmanlı Devleti'nin kurtuluşu için çok sayıda fikrin ortaya çıkmasını sağlamıştır. Bu fikirlerin 
en temel özetini Kemalizmin milliyetçilik politikalarına yön veren Türkçü aydınlardan Yusuf Akçura'nın "Üç Tarzı-1 Siyaset” adlı kitabında görmek mümkün olacaktır (Akçura, 2015).

"Üç Tarz-1 Siyaset” başlığı altında incelenen görüşler Osmanlıcılık, İslamcılık ve son olarak da Türkçülük fikirleridir. Devletin parçalanma sürecinde gayrımüslim coğrafyayı elde tutan Osmanlıcılık siyasetinin çöküşünün ardından Ortadoğu'daki Müslüman toplumların da devletten ayrılması ile birlikte İslamcıllk siyasetinin de işlevselliğini kaybetmesi devleti Türkçülük siyaseti ile baş başa bırakmıştır (Akçura, 2015: 98). Ancak burada "Türkçülük" kavramına yalnızca kültürel bir anlam yüklemek eksik olacaktır. "Türkçülük", toplumun tüm kesimlerine hitap etme ve toplumu aydınlatma çabası sebebiyle Rus Narodnizminden etkilenen halkçılık kavramının ortaya çıkmasını sağlayacak, ülkede içindeki birlik ve beraberliğin korunabilmesi için Fransız solidarizmiyle tanışacak, ekonomisini bağımlılıktan kurtarabilmek ve ülke adına sermaye biriktirebilmek için de Alman milli iktisat kavramından beslenerek Cumhuriyet döneminde "devletçilik" kavramını inşa edecektir (Akçura, 2013: 13-14).

Kemalizmin inşası sürecinde de iktidarın elindeki kavramlarda çok fazla bir değişiklik yoktur. Ulus-devlet inşası ekseninde "milliyetçilik", siyasal rejimin belirlenmesinde Fransız Devrimi'nden esinlenen "halk egemenliği", uyum içinde bir toplum arayışını simgeleyen "solidarizm", bağımsız bir ekonomi kurabilmek için "milli iktisat", Rus Narodnizminin bir yorumu olan "halkçıllk" kavramlarından oluşan bir düşünsel toplam üzerinden Kemalizmin kuruluşuna tanıklık edilmiştir (Toprak, 2013: 46).

Kemalizmin politik kuruluşundaki ilkeler daha belirgin bir halde iken iktisadi düşüncenin kuruluşunda yine belirli ilkelerden ziyade dönemin politik ve ekonomik gerçekleri üzerine alınan farklı kararlar arasındaki farklılıkları görmek mümkün olacaktır. 1920'li ve 1930'lu yılların iktisadi tercihleri arasındaki farklılık ise temelde Kemalizmin iktisadi ilkelerinin ne olduğuna dair soruya net bir yanıt verilememesini de beraberinde getirmektedir. "Milli iktisat" kavramı ekseninde ülkede bağımsız bir ekonomi kurulması en belirgin olan ilkelerin başında gelmektedir. Bağımsız bir ekonominin kurulması fikrinin bu ölçüde bir değere sahip olmasının en önemli nedeni ise Osmanlı Devleti'nin ekonomik imtiyazları olarak tanımlanan "kapitülasyonlar" sürecinin ülkeyi yarı-sömürge bir devlet haline getirmesidir (Kasaba, 1993: 95). Ekonomik olarak devletin bağımlı bir noktaya doğru ilerlemesi kaçınılmaz bir çöküşs sürecinin de başlangıcını ifade etmektedir. Bu sebeple Osmanlı Devleti'nden Cumhuriyet'e miras kalan en önemli iktisadi kavram "bağımsız bir ekonomi" modelini inşa edebilmektir. Ekonominin bağımsızlığı üzerindeki ortaklık bir yana bırakıldığında bu yeni modelin içeriğinin ne olacağı ülke içinde oldukça önemli bir tartışma konusu haline gelmiştir. 1920'li y1lların iktisadi tercihleri 1923 yılında gerçekleştirilen İzmir İktisat Kongresi'nde alınan kararlarla oldukça uyumludur (Ökçün, 1997: 204). Devletin yerli bir girișimci sınıf yetiștirmesine dayanan bu yeni politika 1920'li yıllar boyunca işlerlik kazanmıştır (Boratav, 2006: 42). Öte yandan 1930'lu yılların ulusal ve uluslararası ortamı 1929 Dünya Ekonomik Bunalımı'ndan doğrudan etkilenmiş ve iktisadi politikalar üzerinde devletin etkisini artıran, sanayi ve kalkınmaya dayalı korumacı bir politika tercih edilmeye başlanmıştır. 1930'lu yılların iktisadi politikaları tanımlanırken "devletçilik" teriminin tercih edildiği görülmektedir (Bulut, 2003: 94). Devletin özel sektörü gözardı etmeden oluşturduğu bu yeni iktisadi yönelim "milli burjuvazi” sınıfı projesinin rafa kalkmasına ve devletin neredeyse bütünüyle kontrolü eline aldığı yeni bir sürecin ortaya çıkmasına neden olmuştur.

Her iki dönemde alınan kararlar ülkedeki sermaye sınıfının gelişiminde büyük rol oynamış ancak 1920'li y1llarda ticaret burjuvazisinin yükselişine, 1930'larda ise sanayi burjuvazisinin yükselişine tanıklık edilmiştir. 1930'lu yılların en önemli gelişmelerinden biri ise devletin ideolojisinin "altı ok" kavramın ekseninde ortaya çıarıldı $\breve{g}_{1}$ süreçte iktisadi politikaların "devletçilik" oku ile tanımlanması olmuştur. Kemalist iktidar kendi ideolojik yönelimlerini belirlerken resmi bir iktisadi politika tercihini de 1930'lu yıllar itibariyle ortaya koymuş bulunmaktadır (Kaymakçı, 2015: 169). 1930'lu yıllarda iktidarın "devletçilik" olarak tanımladığı 
sürecin içeriğine dair oldukça önemli tartışmaların yapıldığı görülecektir. Bu tartışmaların ana ekseni devletin ekonomideki rolünü tanımlamak olduğu kadar özel sektöre ne ölçüde yer verileceğine dair tartışma Kemalizmin "devletçilik" ilkesi gereğinde iktisadi politikalarının içeriği ile ilgili oldukça muğlak bir ortamın yaratılmasına da neden olmuştur. 1930'lu yılların iktisadi yönelimlerine dair esas olarak sorulması gereken soru şudur: "Kemalizm iktisadi olarak nasıl bir düzen kurmayı amaçlamaktadır?"

Yalnızca hükümetin faaliyetlerine bakıldığında Atatürk'ün 1932 yılında Celal Bayar'ı İktisat Vekilliği makamına getirmesi ve buna bağlı olarak da İş Bankası etrafında yeni bir sermaye sınıfının oluşmaya başladığı görülecektir. Burada Kemalizmin yeni bir finans-kapitali büyütme isteğine dair yorum yapmak oldukça kolay olacaktır. 1932 yılında atılan bu adıma karşılık 1933 yılında bizzat iktidarın talepleri doğrultusunda yayın hayatına başlayan Kadro Dergisi çevresinde de yeni oluşmaya başlayan sermaye gruplarının varlığından oldukça rahatsız, devletin ekonomideki merkezi gücünün artmasına yönelik politika üreten bir söylemin ortaya çıtığı görülecektir. Kapitalizm ve sosyalizm arasında "Üçüncü Yol"u bulmaya çalışan (Yanardağ, 2012: 25), bu arayış içinde de "liberalizm" ile daha çok çatışan bir ekonomi anlayışının devlet içinde yankı bulmaya başladığı da görülecektir (Ertuğrul, 2017: 241-249). Peki Kemalizmin iktisadi modeli bunlardan hangisi üzerine kurulmalıdır? Ya da başka bir deyişle Kemalizmin iktisadi modelini tanımlarken hangi davranışı esas almalıyız?

Atatürk'ün söylemlerinde iktisadi alanla ilgili net önermelere ve çözümlere ulaşmak mümkün değildir. Atatürk'ün bu konudaki tercihlerini ancak yapılan faaliyetlerin üzerinden yapılacak yorumlarla okumak mümkün olacaktır. Şartların değişmesi ölçüsünde Kemalizmin iktisadi yönelimlerinin ve yöntemlerinin de değiştiği görülecektir. Pek çok yorum açısından Kemalizm her döneminde kapitalizmin gelişmesine müsaade ettiği için bu konuda tartışılması gereken bir husus yok gibi görünmektedir. Ancak Kemalizmin iktisat alanındaki temsilinin en sağlıklı olarak hangi kavramlar ve ilkelerle yapılması gerektiği belirsizliğini bir ölçüde korumaya devam ettiği için ekonomi politikaları gibi oldukça önemli bir alan Kemalizmin net bir ideoloji olabilmesinin önüne geçmektedir.

Dönemin gazetelerine göz atıldığı zaman Kemalizme dair görüşlerin pek çok noktada da birbirinden farklılaştığı görülecektir. Dönemin yazarlarının konuyla ilgili genel yaklaşımı Kemalizmin tüm “-izm”lerden bağımsız bir biçimde ifade edilmesine yöneliktir. Ancak buna karşılık farklı yazarlar farklı yönleri ön plana çıkarmakta ve mevcut devlet ideolojisini tanımlarken zihinlerindeki idealleri de bu vasitayla yansıtmaktadırlar. Yakup Kadri, Kemalizme bakarken yalnızca ilgili dönemdeki faaliyetlerine değil geleceğe dönük nasıl bir içerik kazanacağına dair sorular da sormaktadır. Müstakbel Kadro Dergisi'nin yaklaşımını 1927'den haber veren Yakup Kadri, Kemalizmi tamamlanmış ve çerçevesi belli bir ideolojik bütün olarak değil "sürekli devrimcilik" ilkesi ekseninde zamanın ruhuna uygun olarak dönüşen bir düşünce biçimi olarak tanımlamaktadır (Hâkimiyeti Milliye, 1927). Yine ilerde Kadro Dergisi'nin kurucuları arasında yer alacak olan Burhan Asaf ise "Fırka İdeolojisi" başlıklı yazısında Kemalizmin pratik siyasal alandaki tatbikine ağılık veren eleştirel bir yaklaşım sergilemektedir. Ona göre "firka ideolojisi” olarak tanımlanan Kemalizm toplumun yalnızca belli kesimlerine yönelik değil, tüm emekçilere, kadınlara, genç ve yaşl1lara yönelik bir programa sahip olmak mecburiyetindedir. Bu gerçekleşmediği sürece parti belirli bir grubun elinde oy toplamak için çalışan "komitacı" bir görünüm kazanabilir ve süreci geriye götürebilir (İnkılâp, 1930: 1-3). Ahmet Cevat ise Burhan Asaf' 'n tam aksine bir doktrin olarak adlandırdığ 1 Kemalizmin "demokrasi mektebi" olduğunu ve toplumun tüm kesimlerine eşit bir biçimde hitap edebildiğini ifade etmektedir (Muhit, 1931). Aynı gazetenin Mayıs 1931 tarihli 31 numaralı sayısında da imzasız yayınlanan "Dördüncü Büyük Millet Meclisi Kemalizmin Büyük Bir Şaheseridir" başlıklı yazıda Kemalizme sınıfsal bir çatışmaya izin vermeyen, toplumun tüm kesimlerinin ve sınıflarının uyum içinde çalıştığ toplumsal yapının "sınai medeniyete" ulaşma noktasında oldukça önemli adımlar atan, siyasal pratik ağırlıklı bir kavram olarak bakmaktadır (Muhit, 1931: 5). Kemalizmin mevcut diğer ideolojilerden 
farklı ve kendine has özelliklere sahip olduğunu iddia eden farklı yazılar da mevcuttur. Kemalizmin mevcut ideolojilerden farklı olmasının ön plana çıkarılması ülkeye yabancı cereyanların nüfuz etmesinin önlenmesi ile ilgilidir. Doğanay'ın “Türkiye'de İdeoloji Kavgalarına Yer Yoktur" (1938) ve Peyami Safa'nın "Kemalizm, Hayat ve İdeal" başlıklı yazıları (1938) bu görüşe dair diğer önemli köşeyazılarıdır. Dönemin önde gelen simalarından Ahmet Hamdi Başar da Kemalizmin durağan bir ideoloji olmadığını, liberalizm ve sosyalizm deneyimleri dışında alternatif bir modeli kendine has özellikleri ile gerçekleştirmeye vakıf olduğunu iddia etmekte, din kurumunu dogmatik olarak değerlendirip erken dönemden ileri-geri kavgası içinde Kemalizmi "ilerici" bir pozisyona oturtmaktadır (1938).

Kemalizmin teorileşme sürecinde önde gelen isimlerden olan Mahmut Esat Bozkurt'un yazılarında da çok daha detaylı bir biçimde sürecin ve Kemalizmin analiz edildiği görülecektir. Bozkurt'a göre Türklerin öz tarihinden ilham alarak meydana çıkan Kemalizm, ilgili dönemde çöküşe geçtiğini düşündüğü liberal medeniyetin bir alternatifi olarak önce Türkiye'ye sonra da kendi sınırları dışına taşacak olan bir sistemi ifade etmektedir. Toplum-birey arasında kurmaya çalıştı̆̆ dengenin liberalizm ve Sovyet sosyalizmi ötesinde değer kazandığ 1 bu yeni biçim Türkiye'yi geleceğe taşıyacak programın temellerini oluşturacaktır. (Bozkurt, 1932: 3-4). Kazım Nami Duru, "Kamâlisma" olarak ifade ettiği Kemalizmi mevcut başka hiçbir sisteme benzemeyen, içinde herhangi bir mistik ve megaloman bir unsur bulunmamaktadır. Kamâlisma bir realitedir (Duru, 1935). Evren de aynı bakış açısıyla Kemalizmi bir "ülkü" olarak tarif etmektedir. Bozkurt ve Duru'nun görüşlerine paralel olarak benzer noktalardan hareketle yalnız bugün yaşanan değil aynı zamanda ulaşılması gereken bir ülkü olarak görmektedir (Evren, 1935). Falih Rifkı Atay'ın DoğuBatı medeniyet savaşı olarak tanımladığı devrimin fikri (Atay, 1935) Bozkurt'ta iktisadi anlamda "devletçilik" olarak tezahür etmektedir (Bozkurt, 1935). Bozkurt'un birey-devlet dengesi ekseninde kurduğu devletçilik anlayışın bir benzeri Ahmet Emin Yalman'da da ortaya çıkacaktır. Yalman da ferdin siyasetinin ve teşebbüsünün toplumsal siyasetin çerçevesi içinde olması gerektiği konusunda Bozkurt ile benzer bir düşünceye sahiptir (Yalman, 1937).

\section{0’lu Yıllar ve Siyasal Dönüşüm}

1930’lu yıllarda devletin dönüşüm sürecindeki en önemli kırılma noktası hiç şüphesiz 1929 Dünya Ekonomik Bunalımı'nın ardından ekonomi alanındaki değişimlerdir. 1930'lu yıllardan itibaren devletin iktisadi politikalarına artık "devletçilik" kavramı yön vermeye başlayacaktır. Bu yeni yönelim de hiç şüphesiz 1920'li yıllardaki iktisadi politikalardan büyük ölçüde farklılık göstermektedir. Devletin 1930'lu yıllardan itibaren iktisadi politikalarındaki dönüşüm sürecinin bir diğer nedeni de Lozan Antlaşması'na ek imzalanan Ticaret Protokolü'ne göre Türkiye'nin gümrük duvarı inşa etmesini engelleyen maddenin süresinin dolmuş olmasıdır. Protokol'e göre Türkiye 1923-1929 yılları arasında gümrük duvarı inşa edemeyecek ve buna bağlı olarak ülke ekonomisi uluslararasi ticaretin her türlü etkisine maruz kalacaktır (Soysal, 2000: 173-184). Ancak protokoldeki tarihin dolması ile 1929 yılında başlayan ekonomik bunalım sürecinin aynı yıla denk gelmiş olması iktidarın "devletçilik" ekseninde yeni bir ekonomi politika uygulamasını olanaklı kılmıştır.

1930’lu yılların iktisadi devletçiliğine dair tartışmalar bir süreklilik-kopuş ikilemi içinde cereyan etmektedir. Burada süreklilik iddiası taşıyan yazarlar açısından Kemalizmin iktisadi politikaları her iki dönemde de Türkiye'de kapitalizmin inşa sürecini pekiştiren adımların atılmasına neden olmuştur. Her iki dönemde isimleri ne kadar farklı olsa da sonuç itibariyle bir değişiklik yaşanmamıştır (Başkaya, 2009: 123, 298). Buna karşılık meseleyi geçmiş dönemden bir kopuş olarak nitelendiren görüş açısından ise "devletçilik" dönemi Türkiye tarihinde yeni bir sayfanın açılmasını beraberinde getirmiş ve 1920 'li yılların iktisadi politikalarından bambaşka yeni bir yol tercih edilmiştir. Bu noktada bu tartışmaya daha fazla girmeden her iki görüşe de belirli bir mesafede bulunmak suretiyle daha farklı bir noktadan hareket edilmesine ihtiyaç bulunmaktadır. 
Kemalizmin iktisadi yönelimlerine kaynaklık eden ilke "bağımsız bir ekonomik model" kurabilmektir. Buradaki "bağımsızlık" kavramından ilk olarak anlaşılması gereken husus devletin ekonomik olarak başka devlete bağımlı halde olmamasıdır. Osmanlı Devleti'nin Kanuni Sultan Süleyman döneminde başlayan kapitülasyonların 19. yüzyılın ikinci yarısından itibaren devleti iktisadi anlamda bir sömürge haline getirmeye başlaması son dönem Osmanlı idarecilerinin olduğu kadar Türkiye Cumhuriyeti'ni kuran kadro açısından da büyük bir travmanın devam etmesini beraberinde getirmiştir. 1838 Balta Limanı Anlaşması ve 1881 yılında Düyun-1 Umumiye'nin kurulması gibi iki sembolik gelişme Osmanlı Devleti'nin iktisadi bir sömürge olma sürecinin kritik aşamalarını oluşturmuştur (Berkes, 2013: 335-345). Osmanlı Devleti'ne fiilen son veren Mondros Ateşkes Antlaşması ile birlikte devlet, politik ve askeri olarak da bir çöküş sürecine girmiştir. Milli Mücadele dönemine de yansıyan çöküş travması, Cumhuriyetin kurucu iktidarı açısından ideolojik bir pozisyon almayı büyük ölçüde zorlaştırmıştır. Zira daha önce de belirtildiği gibi devletin ideolojik olarak bir "-izm" tercih etmesi dönemin siyasal gerçeklerine uygun düşmediği gibi ülkenin yeni bir bağımlılık sürecine doğru sürüklenmesi ihtimalini barındırmaktaydı (Akşin, 2002: 499).

Devletin dış politikası II. Dünya Savaşı'nın sonuna kadar hassas bir denge üzerine kuruludur. Hatta Milli Mücadele döneminde dahi savaş koşullarına rağmen Türk dış politikasının bir denge arayışı içine girdiği söylenebilir. Özellikle de Lozan Antlaşması sürecinin henüz tamamlanmadığ bir dönemde 1923 yılında gerçekleştirilen İzmir İktisat Kongresi, Türk dış politikasındaki denge arayışının somut örneklerinden birini teşkil etmektedir. Dünyanın iki kutuplu bir sistem içinde girmesi için II. Dünya Savaşı sonrasını beklemek doğru değildir. 1917 Sovyet Devrimi'nin ardından iki kutuplu sürecin koşullarının hazırlanmaya başladığ 1 görülecektir. Dünyanın almaya başladığı bu yeni biçim kapitalizm ve sosyalizm ekseninde yeni bir bölünmenin ortaya çıkması ile sonuçlanmıştır. II. Dünya Savaşı'nda Batı ile SSCB arasında 1945 sonuna kadar kurulan stratejik işbirliği bu sürecin içinde yalnızca bir ara dönem olarak kabul edilmelidir. Dünyanın yeni bir kutuplaşmaya doğru ilerlemesi yeni kurulacak olan Türkiye Cumhuriyeti açısından da önemli bir tercihi beraberinde getirmekteydi.

İzmir İktisat Kongresi literatürde geleceğe dönük olarak iktisadi kararların alındığı bir toplantı olarak ifade edilmektedir. Ancak bu toplantı yalnızca iktisadi mesajların değil aynı zamanda politik mesajların da verildiği bir toplantı olmuştur. Devletin kuruluş sürecinde ortaya çıkan yeni iktisadi model özel sektörün teşvik edilmesi ve bu bağlamda yeni bir girişimci sınıf yaratılması açısından Batıya benzerken, ulusal ve bağımsız bir ekonomi kurulması talebi, devletin ekonominin gelişmesindeki belirleyici gücü açısından da Batıya alternatif bir sistemin benimsenmesini beraberinde getirmiştir. Devlet daha kurulmadan önce dahi temel olarak Batılı bir parlamenter demokrasi hedefiyle kurumlarını oluştururken öte yandan da Batı'nın dünya ölçeğindeki durumunu eleştirel bir değerlendirmeye tabi tutan yönüyle de bu alternatif arayışını sürdürmektedir.

1920’li y1llarda ekonominin "milli burjuvazi” ve “özel sektörün ekonomideki rolü” üzerine kurulmasına karşılık olarak dış politikada SSCB ile kurulan yakın ilişki de devletin denge konusundaki hassasiyetini destekler niteliktedir (Keser, 2000: 122). Buna karşıllk 1930'lu yıllarda devletin ekonomiye müdahalesinin oldukça arttığı, planlı ve kalkınmaya dayalı bir ekonomi modeline geçiş sürecinde, başka bir ifadeyle devletçiliğe geçiş sürecinde, ise SSCB ile gerilimin tırmandığını buna karşılık Batı ile daha yakın ilişkiler kurulduğunu görmek mümkün olacaktır. Kemalizmin kuruluş sürecinde "denge" konusundaki hassasiyet yalnızca dış politika ekseninde değil, ülkenin alternatif ideoloji arayışında da merkezi bir öneme sahiptir. Devletin kendisine yeni bir kimlik arayışının kökeninde "üçüncü yol" kavramının rolünden bahsedilmesi gerekmektedir. "Üçüncü Yol” arayışından kasıt ise temelinde iktisadi bir arayış olarak göze çarpmaktadır. Başka bir ifadeyle devlet kapitalizm veya sosyalizm dışında alternatif bir yol arayışına girmiştir.

Devletin 1930'lı y1llar itibariyle alternatif bir siyaset üretme ihtiyacının bir başka boyutu da tarih alanında gerçekleştirilen çalışmalardır. Atatürk'ün bizzat tarihe olan merakı ve ilgisi Türkiye'de 
1930'lu yıllar itibariyle tarih ve kültür eksenli çalışmaların yoğunlaşmasını beraberinde getirmiştir. Türk Tarih Kurumu (TTK) ve Türk Dil Kurumu'nun (TDK) hayata geçirilmesi devletin tarihe ve kültüre yeni bir yorum getirebilmesinin araçları haline gelmiştir. Bu konu literatürde, yeni bir arayıştan ziyade devletin "resmi ideolojisini” pekiştirmesi için kullandığı bir enstrüman olarak tanımlanmaktadır (Adanır, 2001: 344). Ancak bu görüşe karşılık olarak bu dönemde yapılan çalışmaların belirli bir kararı vermeye yönelik değil yalnızca alternatif bir arayış içine girmeyle sınırlı kaldığını ifade etmek gerekir. Başka bir ifadeyle devletin tarih ve dil eksenli konularda son kararını verdiğine dair genel bir kanı oluşmaktadır. Buna kanıt olarak da "Türk Tarih Tezi" ve "Güneş-Dil Teorisi"nin ortaya çıkarılması gösterilmektedir. Ancak görüleceği üzere birisi "tez", diğeri de "teori”"dir. Yani her iki yaklaşım bir son noktayı değil yanlışlanmaya ve yeniden yorumlanmaya açık bir tarih ve dil görüşünü ifade etmektedir. Bu dönemin ürünlerini kanıt olarak sunmaya çalışan görüşün bu noktadaki haklılı̆̆ 1 tek bir noktada tezahür etmektedir. $\mathrm{O}$ da bu çalışmalarının Atatürk sonrası dönemde oldukça sığ ve sınırlı bir alanda kalması ve geliştirilememesidir. Kemalizmin Atatürk sonrası dönemde kronik hale gelen bir krizi olarak devlet katında Atatürk üzerine kurulan ideolojinin temsilinde ortaya çıkan muhafazakar ve gelişime kapalı eğilimler tarih ve dil alanında da mesafe alınmasını engellemiştir. Bu sebeple Türk Tarih Tezi ve Güneş-Dil Teorisi gibi fikirlerin devletin resmi ideolojisinin bir aracı olduğu ifade edilebilir. Ancak burada gözden kaçan önemli bir nokta vardır. O da 1930'lu yıllarda ortaya konan bu çabanın Avrupa merkezli tarih anlatısına karş1 geliştirilmeye çalışan bir refleks olmasıdır. Tarih ve dil üzerine yapılan her iki çalışma da belirli konularda devletin resmi tezini oluşturmaktan önce mevcut tarih algılarına alternatif yeni bir tarih anlatısının ortaya çıkmasını da sağlamıştır. Avrupa merkezci görüşe karşı yeni bir tarih anlatısı üretme ihtiyacı yalnızca Türkiye'ye özgü bir durum değildir. Emperyalist savaş ve işgallere maruz kalmış, uzun sömürgecilik dönemleri yaşayan pek çok toplulukta Avrupa merkezci yaklaşımlara karşı alternatif bir tarih anlatısı geliştirilmek istenmesi oldukça yaygın görülen bir durumdur.

1930'lu yıllar Kemalizmin ideolojik olarak şekillenmesinin önünü açan birtakım gelişmelere sahne olmuştur. Ülkenin içinde bulunduğu koşulların devleti bir "kimlik" arayışına götürmesi yalnızca iktidar açısından değil dönemin çeşitli aydınları ve yazarları açısından da önemli bir hususu teşkil etmektedir. Çalışmanın konusu itibariyle esas olarak Kadro çevresinden Kemalizm'e bakılmaya çalışılacaktır. Ancak Kadro dışında da Kemalizmi tanımlamaya ve yön vermeye çalışan çeşitli metinlere de göz atmak gerekmektedir. Bu metinlerin başında Şeref Aykut'un "Kamâlizm" (2008) başlıklı çalışması bulunmaktadır. Aykut'un çalışması esas olarak dönemin iktidar partisi olan CHP'nin programını açıklayabilmek üzerine kuruludur. Kitabın altbaşlı̆̆ 1 "CHP Programının İzahı" olarak tercih edilmiş ve ilgili metinde okuyucuya Kemalizmin ideolojik içeriğinin temelleri açıklanmaya çalışılmıştır. Bu çalışma, CHP'nin 1935 yılındaki 4. Kurultay'da alınan kararların ve hazırlanan programın halka aktarılabilmesi için hazırladığı bir metin niteliği taşımaktadır. Aykut'un bu çalışması genel itibariyle CHP'ye ya da Kemalizm'e yeni bir soluk kazandırmak için değil mevcut durumu açıklamaktan öte bir amaç taşımamaktadır (Aykut, 2008). Devrimin teorisi "biricikleştirme" dönemin pek çok yazarının üzerinde detaylı bir biçimde durduğu bir husustur. Teoriyi biricikleştirme çabası Kemalizmi mevcut tüm “-izm”lerden kurtarma ve onu başka hiçbir ideolojiye benzemeyen bir noktaya oturtmaya çalışmaktadır. Ancak Kemalizme bir teorik altyapı ararken diğerlerinden farklılık vurgusu dişında herhangi bir derinlikli analize rastlamak mümkün değildir. Aykut da bu görüşü savunan yazarlardan bir tanesidir (İlyas, 2016: 115). Kemalizmi diğer tüm ideolojilerden ayırma ve onu "sağ-sol" ekseninin dışında tanımlama yaklaşımının bir diğer yorumcusu da dönemin önde gelen isimlerinde Tekin Alp'tir. Alp'in kaleme aldığ "Kemalizm" başlıklı çalışma Aykut'tan farklı olarak mevcut durumu izah etmekle kalmamış ve ona kendi yorumları ekseninde yeni bir yön vermeye de çalışmıştır. Kemalizmin biricikliğini ortaya koymaya çalışırken kullandığı araçlar "kimlik", "medeniyet" ve "laiklik" ekseni içinde vücut bulacaktır. Bu bağlamda da yapılan analizler daha çok üst-yapısal nitelikte değerlendirmeler olacaktır (1998). 


\section{Devletin İdeolojisini Kurmak: Kadro Dergisi Deneyimi}

1930’lu yılların politik arayışı aynı zamanda iktidarın kimlik arayışıdır. Bu kimlik arayışı sürecinde devletin dil, kültür ve tarih konuları ile ilgili attığı adımlar devletin yeni ideolojisinin tanımlanması hususunda oldukça önemli adımların atılmasını sağlamıştır. Bir başka deyişle devletin üst-yapıya dair pek çok konuda adım attığını görmek mümkün olacaktır. Buna karşılık 1929 Dünya Ekonomik Bunalımı'nın ardından devleti ekonomiye daha fazla ağırlık verdiği görülecektir. Burada iki önemli sorun ortaya çıkmıştır. Birbiriyle bağlantılı bu iki sorundan ilki ekonomik krize karşı nasıl bir çözüm bulunacağıdır. Diğeri ise 1920'li yıllarda uygulanan "milli burjuvazi" projesinin artık işlevsel olmadığına ortaya çıkan görüşe alternatif olarak nasıl bir yolun izleneceğidir. 1929 Dünya Ekonomik Bunalımı, devleti ekonomi konusunda yeni sorular sormaya ve yeni cevaplar üretmeye yöneltmiştir (Keser, 2000: 125). Ekonomik krizin ortaya çıkış sürecinde aynı yıl içinde Türkiye'nin gümrük duvarları inşa etmesine dair yasağın ortadan kalması ile birlikte bu yeni arayışların hız kazandığını söylemek mümkün olacaktır. Kadro Dergisi, devletin 1930'lu yıllarla birlikte devletin yeni bir arayış içine girdiği dönemde ortaya çıkacaktır.

Kadro Dergisi'nin kuruluş sürecinde bu hareketin sözcülük görevini üstlenen Şevket Süreyya (Aydemir)'nın 1931 yılında Türk Ocakları'nda yaptığı konuşma çok etkili olmuştur. Zira Şevket Süreyya'nın yaptığı bu konuşma kurum dışında çıkarak ülke genelinde CHP'nin yeni bir ideoloji arayışı içine girdiği şeklinde yorumlanmıştır. Bu konuşmanın ardından Şevket Süreyya'nın 1932 yılında çıkardığı İnkılap ve Kadro adlı çalışma ise Kadro Dergisi’nin kuruluş sürecini hızlandıran bir niteliğe sahiptir. Şevket Süreyya çevresinde toplanan bir grup aydın devletin politik yönelimlerini bir ideoloji etrafinda toplayabilmek için bir çaba içine girmişlerdir. Aydemir çevresinde toplanan aydınlar Burhan Asaf (Belge), İsmail Hüsrev (Tökin) ve Vedat Nedim (Tör) gibi sosyalist kökenden gelen düşünürlerdir (Çavdar, 2003: 32). Kadro Dergisi ile ilgili literatürde gerek aydınların gerekse buna bağlı olarak derginin politik yönelimlerinin Marksizmle alakası olmadığı iddia edilse de konuyla ilgili en net olarak yapılacak yorum dergiyi ortaya çıkaran düşüncenin Marksizmden çok net bir biçimde etkilenmiş olmasıdır. Bunların haricinde kurulacak derginin bir diğer önemli ismi de gerek Türk edebiyatı açısından oldukça önemli bir yere sahip olan gerekse devlet katında aldığı görevlerle bürokraside de çalışma imkanı bulmuş olan Yakup Kadri (Karaosmanoğlu)'dur. Bu ekip, 1932 yılında Kadro Dergisi çatısı altında toplanacak ve 36 sayı boyunca Kemalist devrime ideolojik bir zemin hazırlamaya çalışacaktır.

Kadro Dergisi, 1929 Dünya Ekonomik Bunalımı'nın ardından Türkiye'de "Devletçilik" dönemine geçilen süreçte ortaya çıkan bir yayın organıdır. Kuruluşunda ve çalışmasında Atatürk'ün doğrudan talebinin olması ise derginin o dönemdeki önemini ortaya koyan önemli bir detay olarak göze çarpmaktadır. Kadro, devletçilik döneminin en önemli yayın organlarından biri olarak çoğu eski Türkiye Komünist Partisi (TKP) üyesi olan aydınların öncülügünde yayın hayatına başlamıştır (Demirci, 2006: 37). 1930'lu yılların devletçilik kavramı ile özdeşleşen ruhu ise Kadro ile beraber daha da somutlaşmıştır. Kadro pek çok çalışmada da belirtildiği üzere Kurtuluş Savaşı'nın eyleminin ideolojiye dönüştürülmesi amacını taşımaktadır.

Kadro'nun milliyetçilik kavramı ile ilişkisi ilk olarak "sınıfsız toplum" ideali ile örtüşmektedir. Sınıfsız toplum idealinin milliyetçilik ile ilişkisi ise Türkiye toplumunun çatışmalardan arınmış bir yapı olarak tanımlanması ile ilgilidir (Kayalı, 2010: 16). Kadro'nun "sınıf" kavramının ötesinde tanımladığı toplumsal yapı çatışma halinde değil, devletin geleceği açısından uyum içinde çalışan katmanların oluşturduğu bir niteliğe sahip olmalıdır (Nedim, 1932: 17-21). Türkiye Cumhuriyeti'nin bağımsız bir ülke olabilmesinin yolu ancak ve ancak aynı amaç için çalışan ve işbirliği kavramını temel alan bir toplumun inşasından geçmektedir (Tekeli ve İlkin, 2007: 610). Kadro'nun "sınıfsız" toplum görüşü ile sınıflararası işbirliği hususunda çok daha temkinli davrandığı görülecektir. Zira bu konuyla ilgili bir yazıda sınıfsız bir toplum kurabilmek ile sınıflararası işbirliği meselesi iki ayrı başlık altında incelenmiştir. Marksizmin "sınıfsız toplum” fikri Durkheim'ın 
sınıfların işbirliği kavramından farklı bir noktada değerlendirilmiş ve Durkheim'ın bu görüşünün son tahlilde burjuvazinin işine yarayacağı yönünde yapılan yorum iki yaklaşım arasındaki farkkı daha da belirginleştirmiş̧tir (Tökin, 1934: 24). 1930'ların "Halkçılık" idealinin bir yansıması olan sınıfsız toplum ideali ve buna bağlı olarak devletin geleceği ile toplum içi uyum arasında kurduğu doğrusal ilişki Kadro'nun milliyetçilik anlayışının "devlet" merkezli söylemine ve "yurtseverlik" eksenindeki yorumuna temel oluşturmaktadır. Kadro'nun milliyetçilik anlayışına temel oluşturan bu görüşü 2 . Meşrutiyet'ten 1920'lere miras bir kavram olan "korporatizm" (Parla, 1999: 163) ile de yakından ilişkilendirilmiştir. Kadro'nun "korporatizm" ile olan ilişkisi ise korporatizmin dünya üzerindeki en uç örneği olan faşizmle benzer bir noktada değerlendirilmesine de neden olmuştur. Faşizmle ilişkilendirilmesinin en önemli nedenlerinden biri de Kıta Avrupası'nda yükselen faşist dalganın emperyalist ülkelere karşı "güçlü" devleti ortaya çıkarma girişimlerinin Kadrocular üzerinde yarattığı etkidir. Burada dikkat edilmesi gereken husus faşizmden bir model ithal etmek değil emperyalist ülkelere karşı güçlü bir devletin inşasının yollarını aramaktır (Süreyya, 1932: 5, Kadri, 1933: 29). Faşizme karşı çekinceler ve endişeler ile birlikte faşizmin "sınıf uyuşması" ve "emperyalist" niteliği Kıta Avrupası'nda yükselen faşizme doğrudan cephe almayı da beraberinde getirmiştir (Aydemir, 1933: 8-12; Tör, 1933: 17-21; Belge, 1934: 24-30). Bunun yanı sıra "antiemperyalizm” kavramı da yine Kadro'nun milliyetçilik görüşünün "yurtseverlik” ekseninde yeniden yorumlanmasını sağlamaktadır.

Kadro'nun milliyetçilik kavramına yaklaşımı aynı zamanda iktisadi bir temel üzerine oturtulmaktadır. Zira Kadro'nun politik pozisyonun en iyi anlatan kavramlardan biri "iktisadi milliyetçilik" kavramıdır. 2. Meşrutiyet yıllarında ortaya çıkan "milli iktisat" akımı Cumhuriyetin kuruluş sürecinin de önemli parçalarından biri haline gelmiştir. İzmir İktisat Kongresi'nden 1930'lu yılların "Devletçilik" anlayışına uzanan bu süreçte de "milli iktisat" kavramının belirleyici bir rol oynadığını söylemek mümkündür. Kadro, 1930'lu yılların "Devletçilik" dönemi içinde ortaya çıkan bir yayın organı olarak "milli iktisat" kavramının "devletçilik" kavramı ile eş değerde kullanıldığı bir sürecin öncülüğünü yapmıştır. Kadro'nun "milli iktisat" kavramı ile ilişkisi 2. Meşrutiyet dönemi ve Milli Mücadele döneminin mirası olarak görülebilir. Zira Osmanlı Devleti'nin son döneminden 1929 Dünya Ekonomik Bunalımı'na gelinen süreç ana tartışma konularından biri devletin ulusal ve bağımsız bir ekonomi inşa edebilmesinin yollarını aramaktır (Kaymakçı, 2015: 169). Kadro'nun devletçilik yaklaşımında en belirgin olan husus dönemin anti-liberal yükselişine paralel olarak ekonomideki liberalleşmenin de sert bir biçimde eleştirilmesidir. Kadro'ya göre devlet eliyle zenginleşme süreci belirli bir zümrenin zenginleşmesini ortaya çıkarmıștır. CHP'nin uygulamadaki bu tavrı ise halkçılık ve milliyetçilik ilkelerine doğrudan aykırıdır. Kadro'nun "sınıfsız ve imtiayzsız" bir toplum inşasında ortaya çıktığını iddia ettiği imtiyazlı kesimler Kadro'nun CHP'ye yönelik eleştirisinin temellerinden birini oluşturacaktır (Yetkin, 2013: 2012-2013).

Kadro Dergisi'ni oluşturan ekibin ağırlıklı olarak sosyalist bir geçmişe sahip olmaları bu dönemde gerek dünyaya gerekse Türkiye'ye yönelik bakışlarında diyalektik ve tarihsel materyalizmin bir yöntem olarak kullanılmasını da beraberinde getirmiş̧ir. Zira Kadro açısından da Türkiye'nin bağımsızlığının önünde ortaya çıkan engeller onu yeni bir devrimin eşiğine getirmiş ve devam etmesi gerektiğini iddia ettiği devrim sürecinin de Türkiye'yi daha ileriye taşıyacağına dair bir görüşe sahiptir. Kadro'nun tarih anlayışı bu bağlamda çizgisel ve ilerlemeci bir nitelik taşımaktadır (Keser, 2000: 128). Klasik anlamda Marksizmin yöntemleri ile Türkiye'ye formül üretmeye çalışan Kadro'nun ilk sıklıkla temas ettiği esas noktada ülkenin ekonomik açıdan dönüşümü olacaktır. 1930'lu yıllar boyunca CHP kanadının da ekonomi politikaları ile oldukça yakından uğraşmasına paralel olarak Kadro'nun da ekonomi temelli bir uğraş içinde girdikleri görülecektir. Yaşanan ekonomik krize ve savaş sonrası süreçte yaklaşmakta olan yeni krizlere karşılık olarak daha güçlü bir ekonomik modelin inşa edilmesi gibi bir ihtiyacın ortaya çıtığı görülecektir. Bu da Türk ekonomisinde "kalkınma" kavramının hızlı bir biçimde yeni döneme damgasını vurmasını sağlamıştır. Kalkınma anlayışını destekleyen bir diğer kavram ise "planlama" 
kavramı olacaktır (Tökin, 1933: 26). Sosyalist bir planlama modelini oldukça çağrıştıran bu yeni model esas olarak sosyalist bir ekonomiyi hedeflemese de devlete ekonomik alanda çok daha büyük ve önemli yetkilerin verilmesini sağlamıştır (Yanardağ, 2012: 144). "Planlı kalkınma" ilkesinin 1930'lu yıllara esas niteliğini veren "devletçilik" kavramı ile yanyana gelmesiyle ortaya "iktisadi devletçilik" kavramının çıktığı görülecektir (Aydemir, 1932: 5). "Devletçilik" ilkesinin Kemalizmin prensiplerini formülleştiren "altı ok" içinde dahil olması ise 1930'lu yılların bir gerçeği olarak karşımıza çıkacaktır.

Kadro'nun bu noktadaki rolü yeni bir “iktisat devleti” olarak şekillenen Türkiye Cumhuriyeti'nin bu yöneliminin içini doldurmak olacaktır. Sanayileşmeye ağırlık veren bir ekonominin devlet eliyle üretime dönük bir program belirlemesi Kadro'nun hangi noktalardan hareket edeceğini de büyük ölçüde belirlemiştir. Kalkınmacı ve planlamacı bir ekonomi tercihi bir sonuç değil ancak bir hareket noktası olabilir. Bu tercihi bir hedefe doğru götürebilmek için de Kadro'nun bir ideolojik açılım yapması gerekmektedir. Ancak Kadro'nun Türkiye'ye dair çözüm önerilerinden önce güncel konjonktürü nasıl ve hangi kavramlarla okuduğuna dair bir giriş yapılması gerekmektedir. Kadro'nun 1930'lu yılların dünyasını algılamaya çalışırken "başat çelişki”" arayışından hareket edildiği görülecektir. Marksizmin klasik yöntemleri üzerinden yapılan politik değerlendirmelerin doğal bir sonucu olarak Kadro, dönemin politik gerçekliğini "emperyalizm" teorisi üzerinden anlamaya çalışmaktadır. Bu emperyalizm teorisi ise dünyadaki temel çelişkinin sömüren ülkelerle sömürülen ülkeler arasında ortaya çıkması üzerine kuruludur (Yanardağ, 2012: 139). İlgili teorinin Lenin'in emperyalizm kuramında "ezen-ezilen halklar" arasındaki ayrıma oldukça yakın olduğunu ifade etmek mümkündür. Bunun yanı sıra Lenin döneminde "ulusal kurtuluş savaşları" ekseninde ortaya çıkan pragmatik tavır da yine Kadro'nun siyasal görüşleri ile önemli benzerlik göstermektedir. Kadro'nun bu noktada Lenin'in yaklaşımından fark1, ulusal kurtuluş savaşlarına pragmatik bir çerçevede yaklaşmaması, aksine ulusal kurtuluş savaşı söyleminin bizzat içinden konuşmasıdır (Aydemir, 1968: 46).

Kadro açısından dünya bir emperyalizm çağı içinde yaşamaktadır. Ancak bu emperyalizm çağı artık son dönemindedir. İki dünya savaşı arası dönemde liberal ve barış eksenli söylemlerin yerini milliyetçi ve otoriter söylemlerin aldığı görülecektir. Kıta Avrupası'nda faşizmin ve Nazizmin ortaya çıkması ile sonuçlanan bu dönemlerde Batı'nın politik gücünün gerilemesini talep eden devletler açısından emperyalizmin tamamen ortadan kalkacağına dair fikirler ortaya çıkmaya başlamıştır. Türkiye örneğine bakıldığında ise Kadro Dergisi'nin bu dönemde yoğun bir biçimde Batı emperyalizminin gerilemesi ile ilgilendiğini söylemek gerekmektedir. Kadro'nun bu döneme dair iki önemli tespiti bulunmaktadır. Bunlardan ilki emperyalizm çağının son bulacağıdır. Batı'nın politik ve ekonomik gücünün gerileyeceğini düşünen Kadro, artık yeni bir çağın başlamakta olduğunu da haber vermektedir. İkinci önemli tespitini oluşturan bu görüş ise dünyada "ulusal kurtuluş savaşları" çağının başlayacağına yöneliktir (Türkeş, 1998: 115).

Batı'nın emperyalist siyasetine karşı daha milliyetçi ve otoriter söylemlerin ortaya çıkması, özellikle de İtalya, Almanya ve Türkiye örneği arasında çeşitli benzerliklerin de oluşmasını beraberinde getirmiştir. Hatta çeşitli yorumlar Türkiye'nin de bir çeşit "faşizm" olduğuna dair görüşler ortaya atmışlardır (Adanır, 2011: 353). Bir dünya savaşı sonrasında ortaya çıkan ve yeni kurulan bir ulus-devleti temsil eden Türkiye'nin yeni ve muhtemel bir savaşın arefesinde otoriterleşme eğilimi göstermesi özcü bir niyeti değil, yaklaşan krize karş1 önlem almak olarak yorumlanmalıdır. "Güçlü ve bağımsız bir devlet" hedefi ile liberal demokrasinin tezlerinin çöktüğünün ilan edilmesi gibi söylemler üzerinden Türkiye'nin klasik bir Kıta Avrupası faşizmi ile yan yana değerlendirilmesi hatalı bir yorum olarak ortaya çıkmaktadır (Yanardağ, 2012: 150). Kadro'nun dış politikadaki iddiaları yalnıza dergi çevresini değil, Atatürk'ün icazetiyle yayımlanan bir dergi olarak iktidarın da görüşlerini dolaylı olarak bağlayan bir niteliğe sahip olmuştur. Zira Atatürk dönemine dair yapılan eleştirilerin arkasında Kadro Dergisi'nin politik tezlerinin de olduğunu söylemek yanlış olmayacaktır. 
Kadro Dergisi uzun süreli bir yayın organı olamamıştır. Derginin özellikle de iktisadi görüşleri dönemin siyasal tercihleriyle farklı noktalara temas etmeye başlamıştır. Derginin politik duruşunun yanı sıra Atatürk ve Bayar ile İnönü arasındaki gerginlik de derginin kaderini belirleyen bir unsur olmuştur. Derginin kapanma sürecinde genel olarak ifade edilen husus Atatürk ile Kadro arasındaki görüş ayrılıkları olarak belirtilmektedir. Literatürde yaygın olan bu görüşe karşılık Bayar'a yakınlığı ile bilinen İsmet Bozdağ'ın bu konu ile ilgili görüşleri farklı bir bakış açısının ortaya çıkmasını da sağlamaktadır. Bozdağ, esasında Atatürk ile İsmet İnönü’nün devletçilik konusundaki görüşlerinin birbirine çok daha yakın olduğu belirtmiştir (Bozdă̆ 2000: 64). Ancak İnönü ile yaşadığ 1 gerginlik ve Bayar'ın tercih edilmesi ile birlikte İnönü ve İnönü'nün destek verdiği Kadro'nun da devletçilik görüşleri rafa kaldırılmıştır. Bu yorum göstermektedir ki Kadro Dergisi, Atatürk'ün 1930'larda çok daha belirgin hale gelen devletçilik anlayışının doğal bir sonucu olarak ortaya çıkmıştır. Ancak İnönü ile yaşadığı gerilimle birlikte dergi ile benzer görüşlere sahip olmasına rağmen derginin kapanma sürecinde de role sahiptir. Başka bir ifadeyle Atatürk'ün Kadro ile ilgili problemi düşünsel değil dönemin iktidar içi çatışmaları sebebiyle yönetimseldir.

\section{Kadro Dergisi'nin Kemalist İktidarın Siyasal Yönelimleri Açısından Değerlendirilmesi}

Kadro'nun Kemalist iktidarının görüşlerinin belirlenmesi açısından çok önemli bir rol oynadığını söylemek mümkündür. Her şeyden önce Kadro, Atatürk'ün entelektüel arayışlarının bir sonucu olarak ortaya çıkmıştır. Yeni bir ulus-devletin kuruluş sürecindeki kimlik arayışı aynı zamanda entelektüel bir çabayı da beraberinde getirmektedir. Dönem açısından Şevket Süreyya ve beraberinde ekip 1930'lu yıllarda entelekütel bir tartışma zemininin yaratılması açısından uygun figürlerdir. Kadro Dergisi'nin doğuşu böylesi bir ihtiyacı karşılaşmaktadır. Ayrıca Kemalist iktidar açısından, özellikle de Atatürk açısından, devrim bitmiş değildir. Altı ok ilkelerinden biri olan "devrimcilik" ilkesi gereğince devlet ve toplum sürekli bir dinamizm halindedir ve çağın gereklerine uygun olarak gelişim göstermelidir. Kemalist iktidarın erken dönemine dair yapılan eleştiriler Cumhuriyetin kurulmasının ardından değişim ve dönüşüm sürecinin durduğu ve bir çeşit muhafakazarlaşmanın başladığı yönündedir. $\mathrm{Bu}$ eleştiri yapılırken Kemalizmin özünde "muhafazkar" olduğu için sistemin durağan hale geldiğine mi odaklanacağız yoksa dönemin siyasal gerçeklerinin ülkeyi getirdiği noktaya ve iktidar içi yaşanan krizlere mi?

İkinci yorum dönemi saha sağlıklı bir biçimde analiz edebilmek açısından çok daha gerçekçidir. Zira Kemalist iktidar bir yandan güncel krizler ile meşgulken diğer yandan ülkenin geleceğine dair de bir vizyon çizmek istemiştir. İktidar içi bloklaşmalar ve bu durumun bir krize doğru dönüşmesi, geleceğe dönük somut adımların atılmasında önemli bir engel etmiştir. Kadro'nun bu çatışma içinde doğrudan bir tavır aldığını söylemek mümkün olmasa da geliştirdiği politik perspektif stratejik olarak Atatürk'ün kararları ile aynı doğrultuda olmamıştır. Bunun en somut örneğini "devletçilik” ile ilgili yaşanan krizde görmek mümkün olacaktır. Devletçilik fikri, 1930'lu yıllara karakterini veren bir kavram olarak karşımıza çıkmaktadır.

Ekonomik içeriği oldukça kuvvetli olan devletçilik, Kemalizmin ilkelerinden biri haline gelmiş̧ir. Devletçilik fikrinin bu denli önem kazanmasındaki ilk etki hiç şüphesiz Atatürk'ün Dünya Ekonomik Bunalımı'na karşı geliştirmeye çalıştığı çözümde aranmalıdır. Atatürk'ün yanı sıra Başbakan İsmet İnönü de devletçilik fikrinin kuvvetli bir savunucusu durumundadır. Atatürk ile İnönü'nün devletçilik konusunda uzlaşmalarına rağmen hükümetin ilgili dönemde net adımlar atamaması buna karşılık olarak Celal Bayar çevresinin İş Bankası eliyle ortaya koyduğu projelerin kısa vadede sonuç vermesi stratejik olarak Atatürk'ün Celal Bayar ile yakınlaşmasını beraberinde getirmiştir. İktisat Vekilliği'ne getirilen Celal Bayar'ın ülkedeki ekonomik gidişatın sorumlusu haline gelmesi İnönü'nün ekonomi gibi kritik bir konuda ikinci planda kalmasını sağlamıştır. Hükümetin lideri olarak politik gücünü devam ettirmek isteyen İnönü’nün 1932 y1lından sonraki tercihi kendi gücünü gösterebilmek için gerekirse Atatürk'le dahi karşı karşıya gelebilmek olmuştur. 
Atatürk ile İnönü arasında başlayan politik gerginlik Kadro Dergisi’nin geleceğini de olumsuz yönde etkileyen nedenlerden biri haline gelmiştir.

Zira bu dönemde İnönü, devletçilik ile ilgili fikirlerini açıklayabilmek için Kadro Dergisi’ni deyim yerindeyse bir araç olarak kullanmıştır. İnönü’nün ekonomiye dair fikirlerinin derinliğine inmek mümkün değildir. Bu konuda yapılabilecek tek yorum İnönü'nün ekonomi konusunda yeterli bir tecrübeye sahip olmadığıdır. Devletçilik konusunda katı bir tutumu da olmayacaktır. Bu bağlamda Kadro Dergisi'nin İnönü açısından araçsallaştığını ifade etmek mümkündür. Zira II. Dünya Savaşı'nın ardından İnönü'nün Cumhurbaşkanlığı döneminde Kadro Dergisi'nin en önde gelen isimlerinden Şevket Süreyya Aydemir'in içinde bulunduğu bir ekibin hazırladığ 1 "kalkınma planı" kabul edilmeyecek, Amerikan tandanslı bir kalkınma planı onaylanacaktır. Atatürk'e karş1 Kadro'nun arkasında duran İnönü aynı tavrı savaş sonrası süreçte göstermemiştir. Yine de 1930'lu Kadro'nun "iktisadi devletçilik" yaklaşımını benimsemiş görünen İnönü’nün bu görüşü Atatürk'ün Bayar tercihine karşı bir muhalefet söylemi olarak kullandığını da dikkate almak gerekmektedir. Kadro sayfaları üzerinden yaptığı ekonomik yorumların muhalif bir sese doğru dönüşmesi ideolojik olarak olmasa da iktidar içi güç mücadelesi ekseninde Kadro'nun geleceğini de olumsuz yönde etkilemiştir. Atatürk'ün güçlü politik liderliği ve tek parti dönemi boyunca kendisine güçlü bir biçimde muhalefet edebilme imkanının oldukça zayıf olması İnönü’nün bu çıkışı karşısında bir müdahaleyi de beraberinde getirmiştir.

İkinci bir husus ise Atatürk ile Kadro arasında düşünsel bir gerilimden ziyade yönetimsel bir gerilim olmasıdır. 1930'ların krizleri devlet yönetiminde hızlı ve işlevsel adımların atılması ihtiyacını doğurmaktadır. Dünyanın yeni bir savaşa hazırlanma sinyallerinin verildiği 1930'lu yılların ilk yarısında Türkiye, savaştan uzak durarak en düşük seviyede zararla muhtemel bir savaş1 atlatmak istemektedir. Aynı zamanda bir dünya ekonomik bunalımı tecrübesi yaşayan Türkiye ekonomi politikalarına öncelik vermiştir. Ekonomiye verilen öncelik ise bu konuda atılan ve/veya atılacak olan adımların çok daha kritik önemde olmasına neden olmaktadır. Bayar ile İnönü arasında yaşanan gerilimde Bayar'ın galip gelmesinin arkasında iktisadi görüşlerinin ilkelerinden ziyade dönemin koşullarında konu ile ilgili daha çok adım atabilmesi yatmaktadır. Bu bağlamda da Atatürk'ün Bayar tercihini basit bir biçimde düşünsel yakınlık olarak görmek eksik bir yorum olacaktır. Atatürk'ün "kısa zamanda büyük işler başardık" söyleminin arkasında 1930'lu yıllar gibi kritik bir dönemde mümkün olduğu kadar fazla adım atabilmenin her şeyden daha önemli olduğunu görmek gerekmektedir. İnönü, Başbakan olarak bir bakana karşı geride kalmış ve aradaki fark1 makamının gücünü kullanarak kapatmaya çalışmıştır. Bu durum ise Atatürk, Bayar ve İnönü arasında yönetimsel bir krizin ortaya çıkmasını sağlamıştır. Bu krizde ise İnönü’nün tavırları Atatürk'ün Bayar'1 tercih etmesinde oldukça belirleyici olmuştur. Kadro'nun ekonomik olarak özel sektörü ve liberal fikirleri mahkum eden görüşleri, buna karşılık olarak burjuvaziyi ikinci plana alan ve devleti temel belirleyici olarak ön plana çıkarması Bayar gibi liberal görüşlere sahip bir gücün yükselişinde Kadro'nun gerilemesini de beraberinde getirmiştir. Atatürk'ün Kadro'nun kapanış sürecine ve eş zamanlı olarak Bayar'ın yükseliş sürecinde bu gelişmeleri de dikkate almak gerekmektedir.

\section{Sonuç}

Kemalizmi evrensel ideolojiler ile aynı noktada tanımlamak mümkün değildir. Bunun en önemli sebeplerinden bir tanesi de Kemalizmin bir yarı-sömürge devlet içinde ortaya çıkmış olmasıdır. Aynı zamanda Milli Mücadele'nin siyasal pratiği içinden doğmaya çalışan bir akım olarak ülkenin kuruluş sürecinden sonra, başka bir ifadeyle pratikten sonra, sınırları daha belirgin hale gelmeye başlamıştır. Türkiye Cumhuriyeti'nin kuruluş sürecindeki iktidarın beslendiği bir takım ideolojiler olmasına rağmen Kemalizmin ortaya çıkış sürecinde net bir ideolojinin izlerini görmek mümkün değildir. Dönemin siyasal gerçekliklerinin bir sonucu olarak Kemalizmi herhangi bir "izm"e indirgemek oldukça zordur. Bu sorun yeni bir ulus-devletin kuruluş sürecinde devletin bir politik kimliğe sahip olmasını geciktirecektir. 1935 yılındaki CHP Kurultayı'nda telaffuz edilen ve 
daha sonradan Kemalizm olarak değiştirilecek olan "Kamâlizm", yeni devletin siyasal kimliğinin inşasında önemli bir geçiş aşamasını oluşturacaktır. Yönetim katında atılan bu adımların ötesinde bizzat Atatürk'ün talimatları ile bir araya gelen Kadro Dergisi'nin entelektüel alanda böyle bir amaca hizmet etmesi talep edilmiştir. İlk döneminde özellikle de dış politika ekseninde çok daha derinlikli analizler yapan ve iktidarın uygulamaları ile oldukça paralel bir yol takip eden Kadro, ülkenin ekonomi politikalarına bir yön vermeye çalışırken iktidar ile çelişkili bir sürece girmiştir. Kemalist iktidarın "milli burjuvazi" projesini rafa kaldırdığı 1930'lu yıllarda bir başka taraftan "aferistler" olarak bilinen ve İş Bankası çevresini oluşturan Celal Bayar ve çevresi, Bayar'ın iktisat vekilliği ile birlikte daha da güçlenmiş ve Kadro'nun siyasal perspektifinin oldukça dişında bir gelişim göstermeye başlamıştır. Dönemin iktidar mücadelesi içinde İnönü'ye karşı Bayar'ı tercih eden Atatürk'ün bu tavrı da Kadro ile arasındaki gerginliğin dönemsel ve taktiksel mi yoksa derinlikli bir düşünsel farklılık mı olduğuna dair pek çok soru işaretinin ortaya çıkmasını da sağlamıştır. Yapılan yorumlar Atatürk ile Kadro arasındaki görüş farklılıklarına daha fazla yer verse de Kadro dergisinin Kemalizmi geliştirme sürecindeki rolünün dönemin siyasal çekişmelerine kurban gittiğini ve gelişen sürecin yalnızca Atatürk'ün kontrolünde olmadığını da düşünmek gerekmektedir.

\section{Kaynakça}

A. Cevat (Emre). "Kemalizm ve Demokrasi." Muhit, S. 30, Nisan 1931, 1-3'ten aktaran Halıc1, Ş., M. Burgaç (2016). Altı Ok (1919-1938). İstanbul: Kaynak Yayınları. 262-265.

Adanır, F. (2001). Kemalist Authoritarianism and Fascist Trends in Turkey During Inter-War Period. (ed.) S. U. Larsen. Fascism Outside Europe: The European Impulse Against Domestic Conditions in the Diffusion of Global Fascism. (ed.). S. U. Larsen. New York: Columbia University Press. 313-361. https://doi.org/10.1111/1469-8219.00107

Akçura, Y. (2013). Türkçülü̈ğün Tarihi. (ed.) S. Perinçek. İstanbul: Kaynak Yayınları.

Akçura, Y. (2015). Üç Tarz-ı Siyaset. (ed.) E. Kılınç. İstanbul: Ötüken Neşriyat.

Akşin, S. (2002). “Atatürkçülük İdeolojisinin Billurlaşma Süreci.” Cumhuriyet Döneminde Siyasal Düşünce ve Modernleşme. (der.) A. A. Dikmen. Ankara: İmaj Yayınc1lık. 495-507.

Atay, F. R. (1935). “Davamız.” Ulus, 19 Mayıs 1935’ten aktaran Halıcı, Ş., M. Burgaç (2016). Altı Ok (1919-1938). İstanbul: Kaynak Yayınları. 278-279.

Aydemir. Ş. S. (1933). "Beynelmilel Fikir Hareketleri Arasında Türk Nasyonalizmi II. FAŞi̇ZM." Kadro, 2(18): 8-12.

Aydemir. Ş. S. (1933). "Beynelmilel Fikir Hareketleri Arasında Türk Nasyonalizmi III. Türk Nasyonalizmi." Kadro, 2(21): 9.

Aydemir, Ş. S. (1968). Inkılap ve Kadro. Ankara: Bilgi Yayınevi.

Aykut, Ş. (2008). Kamâlizm (CHP Programının İzahı). 2. Baskı. İstanbul: Kaynak Yayınları.

B. Asaf (Belge) (1930). "Fırka İdeolojisi.” İnkılap, 28 Eylül 1930'dan aktaran Halıcı, Ş., M. Burgaç (2016). Altı Ok (1919-1938). İstanbul: Kaynak Yayınları. 255-256.

Başar, A. H. (1937). “Atatürk'ün İdeolojisi.” Cumhuriyet, 7 Kasım 1937'den aktaran Halıcı, Ş., M. Burgaç (2016). Altı Ok (1919-1938). İstanbul: Kaynak Yayınları. 300-303.

Başkaya, F. (2009). Devletçilikten 24 Ocak Kararlarına: Türkiye Ekonomisinde İki Bunalım Dönemi. Ankara: Özgür Üniversite Kitaplığı.

Belge, B. A. (1934). “1933-1934 Bir Yılbaş1 Bilançosu.” Kadro, 3(25): 24-30. 
Berkes, N. (2013). Türkiye İktisat Tarihi. İstanbul: Yapı Kredi Yayınları.

Boratav, K. (2006). Türkiye'de Devletçilik. Ankara: İmge Yayınları.

Bozdağ, İ. (2000). Devlet Kavgası. İstanbul: Tekin Yayınevi.

Bozkurt, M. E. (1935). “Kamâlizmin İdeolojisi.” Tan, 27-28 Mayıs 1935’ten aktaran Halıcı, Ş., M. Burgaç (2016). Altı Ok (1919-1938). İstanbul: Kaynak Yayınları. 280-281.

Bulut, M. (2003). “1929 Dünya Ekonomik Buhranı ve Türkiye'de Devletçiliğe Geçiş.” Bilig, 4: 77101.

Çavdar, T. (2003). Türkiye Ekonomisinin Tarihi 1900-1960. Ankara: İmge Yayınları.

Demirci, F. (2006). "Kadro Hareketi ve Kadrocular." Dumlupınar Üniversitesi Sosyal Bilimler Dergisi, 15: 35-53.

Doğanay, Ş. (1938). “Türkiye'de İdeoloji Kavgalarına Yer Yoktur.” Varlık, 15 Şubat 1938'den aktaran Halıcı, Ş., M. Burgaç (2016). Altı Ok (1919-1938). İstanbul: Kaynak Yayınları. 304306.

"Dördüncü Büyük Millet Meclisi Kemalizmin Büyük Bir Şaheseridir.” Muhit, S. 31, Mayıs 1931, 5'ten aktaran Halıcı, Ş., M. Burgaç (2016). Altı Ok (1919-1938). İstanbul: Kaynak Yayınları. 266-267.

Duru, K. Nami. (1935). "Bizim Halkçılı̆̆ımız Kamâlismanın Evrenselliği." Cumhuriyet, 9 Mayıs 1935 'ten aktaran Halıcı, Ş., M. Burgaç (2016). Altı Ok (1919-1938). İstanbul: Kaynak Yayınları. 273-275.

Ertuğrul, İ. (2017). Devletçiliğin Ayak İzleri. Ankara: Telgrafhane Yayınları.

Evren, N. (1935). “Altı Ok Kamumuzun Ülküsüdür!.” Babalık, 31 Mart 1935’ten aktaran Halıc1, Ş., M. Burgaç (2016). Altı Ok (1919-1938). İstanbul: Kaynak Yayınları. 276-277.

İlyas, A. (2016). "Kemalizmin Propaganda Araçları veya Araçsızlı̆̆ı", The Journal of Social Sciences Studies, 51: 113-125. https://doi.org/10.9761/jasss3541

Kasaba, R. (1993). Osmanlı İmparatorluğu ve Dünya Ekonomisi: Ondokuzuncu Yüzyıl. (çev.) K. Emiroğlu. İstanbul: Belge Yayınları.

Kayalı, K. (2010). Türk Düşünce Dünyasının Bunalımı. İstanbul: İletişim Yayınları.

Kaymakçı, Ö. B. (2015). Osmanlı'dan Cumhuriyet'e Türkiye Ekonomisi: Tarihi-Düşünsel Bir Deneme. İstanbul: Ötüken Neşriyat.

Keser, İ. (2000). Türkiye'de Siyaset ve Devletçilik. Ankara: Gündoğan Yayınları.

Kışlalı, A.T. (2000). Siyasal Sistemler: Siyasal Çatışma ve Uzlaşma. Ankara: İmge Yayınları.

Köker, L. (2002). "Kemalizm/Atatürkçülük: Modernleşme, Devlet ve Demokrasi." Modern Türkiye'de Siyasi Düşünce Kemalizm. (ed.) Ahmet İnsel. İstanbul: İletişim Yayınları. 97111.

M. Esat (Bozkurt) (1932). “Kemalizm.” Anadolu, S. 5452-5453, Kasım 1932, 3-4'ten aktaran Halıc1, Ş., M. Burgaç (2016). Altı Ok (1919-1938). İstanbul: Kaynak Yayınları. 268-271.

Mardin, Ș. (2013). Türkiye'de Toplum ve Siyaset. (der.) Mümtazer Türköne, Tuncay Önder. İstanbul: İletişim Yayınları.

Nedim, V. (1932). "Sınıflaşmak ve İktisat Vaziyeti." Kadro, 1(11): 17-21. 
Ökçün, A. G. (1997). Türkiye İktisat Kongresi 1923-İzmir: Haberler-Belgeler-Yorumlar. Ankara: Sermaye Piyasası Kurulu Yayınları.

Parla, T. (1999). Ziya Gökalp, Kemalizm ve Türkiye'de Korporatizm. (der.) F. Üstel, S. Yücesoy. İstanbul: İletişim Yayınları.

Safa, P. (1938). "Kemalizm, Hayat ve İdeal.” Cumhuriyet, 13 Eylül 1938'den aktaran Halıcı, Ş., M. Burgaç (2016). Altı Ok (1919-1938). İstanbul: Kaynak Yayınları. 307-310.

Soysal, İ. (2000). Türkiye'nin Siyasal Andlaşmaları 1. Cilt (1920-1945). Ankara: Türk Tarih Kurumu Yayınları.

Sönmez, E. (2012). Ahmed Rlza: Bir Jön Türk Liderinin Siyasi-Entelektüel Portresi. İstanbul: Tarih Vakfi Yurt Yayınları.

Süreyya, Ş. (1932). “Genç Nesil Meselesi.” Kadro, 1(4): 5.

Tekeli, İ., S. İlkin. (2003). Kadrocuları ve Kadro'yu Anlamak. İstanbul: Tarih Vakfi Yurt Yayınları.

Tekinalp (1998). Kemalizm. (çev.) Ç. Yetkin. İstanbul: Toplumsal Dönüşüm Yayınları.

Toprak, Z. (2013). Türkiye'de Popülizm 1908-1923. İstanbul: Doğan Kitap.

Tökin, İ. H. (1934). "Millet İçinde Sınıf Meselesi II.” Kadro, 3(26): 20-26..

Tökin, İ. H. (1933). "Milli Kurtuluş Devletçiliği." Kadro, 2(19): 23-31.

Tör, V. N. (1933). "Sanayileşme Davası." Kadro, 2(24): 17-21.

Türkeş, M. (1998). "The Ideology of the Kadro (cadre) movement: a patriotic leftist movement in Turkey." Middle Eastern 119.https://doi.org/10.1080/00263209808701245

Türkeş, M. (1999). Ulusçu Sol Bir Akım: Kadro Hareketi (1932-1934). Ankara: İmge Yayınları.

Y. Kadri (1933). “Ankara-Moskova-Roma.” Kadro, 2(13): 29.

Y. Kadri (Karaosmanoğlu) (1927). "Kemalizm.” Hakimiyet-i Milliye, 20 Ağustos 1927'den aktaran Halıcı, Ş., M. Burgaç (2016). Altı Ok (1919-1938). İstanbul: Kaynak Yayınları. 249-251.

Yalman, M. E. (1937). “Altı Esasın Kapsamı.” Tan, 9 Şubat 1937’den aktaran Halıcı, Ş., M. Burgaç (2016). Altı Ok (1919-1938). İstanbul: Kaynak Yayınları. 290-292.

Yanardağ, M. (2012). Kadro Hareketi: Dünya'da ve Türkiye'de Ulusçu Sol ve Üçüncü Yol Arayışının İdeolojik Kaynakları. İstanbul: Destek Yayınları.

Yetkin, Ç. (2013). Siyasal Düşünceler Tarihi V. İstanbul: Gürer Yayınları.

Zürcher, E.J. (2014). Modernleşen Türkiye’nin Tarihi. İstanbul: İletişim Yayınları. 